\section{Evaluation of Daphne Germplasm for Resistance to Daphne Sudden Death Syndrome Caused by the Soil-borne Pathogen Thielaviopsis basicola}

\author{
David Noshad ${ }^{1}$ and Andrew Riseman \\ UBC Botanical Garden and Centre for Plant Research, University of British \\ Columbia, 6804 SW Marine Drive, Vancouver, BC, V6T 1Z4, Canada
}

\author{
Zamir Punja \\ Department of Biological Sciences, Simon Fraser University, Burnaby, BC, \\ V5A 1S6, Canada
}

Additional index words. Daphne cneorum, disease resistance, root pathogen, Chalara elegans, pathogen challenge, ornamental plants, Rose daphne, garland flower

\begin{abstract}
Many daphne cultivars are susceptible to fungal root pathogens and require frequent fungicide applications during production. To identify taxon differences to disease susceptibility, we evaluated 32 Daphne species and cultivars for resistance to the soilborne pathogen, Thielaviopsis basicola (Berk. and Broome) Ferr., by both in vitro- and in vivo-based methods. Disease-free plant roots were inoculated with the pathogen through topical application of a spore suspension and observed weekly for disease development/ progression. Significant variation for disease severity among the taxa evaluated was determined using a plant disease index. Plant reactions ranged from highly resistant, e.g., $D$. tangutica and $D$. retusa, to highly susceptible, e.g., $D$. cneorum. In addition, a high correlation was found between the in vitro and in vivo techniques for the seven selected species, indicating that they are comparable. However, the in vitro assay provided results in significantly less time than the in vivo assay.
\end{abstract}

The genus Daphne L. (Thymelaeaceae Juss.) is comprised of $\approx 95$ species (Flora of China, in press) distributed through Africa, northern and southern Europe, the Middle East, Asia, and regions of Oceania. Of these species, several species have been commercialized because of their many desirable horticultural characteristics, including attractive foliage, plant habit, flower color, and most of all, pleasant fragrance. Specifically, D. cneroum L. (Rose daphne or garland flower) has become one of the most popular perennial flowering shrubs among ornamental plant growers. However, the genus has acquired a poor reputation because of poor long-term performance of this and other Daphne introductions. One of the major limitations to daphne's survival in cultivation is Daphne Sudden Death Syndrome (DSDS), a disease incited by the fungal root pathogen Thielaviopsis basicola (Berk. \& Br.) Ferraris (syn. Chalara elegans Nag Raj et Kendrick) (Noshad et al., 2006). This disease kills plants quickly, as the name suggests, following the first foliar symptoms. Observations on

Received for publication 22 Mar. 2007. Accepted for publication 24 June 2007.

We thank the H.R. Eddie Foundation for their financial support.

We thank Dr. R. J. Copeman for his helpful suggestions and comments.

${ }^{1}$ To whom reprint requests should be addressed; e-maildnoshad@interchange.ubc.ca.
DSDS-infected plants indicate the following progression of symptoms: 1) brown to black necrotic lesions on the roots, 2) leaf chlorosis leading to abscission, 3) whole plant stunting, and 4) stem collapse and plant death (Noshad et al., 2006).

Thielaviopsis basicola is a fungus common in both cultivated and noncultivated soils (Adams and Papavizas, 1969; King and Presley, 1942; Nag Raj and Kendrick, 1975; Yarwood, 1981) and is generally considered a facultative parasite (Anderson and Welacky, 1988; Bottacin et al., 1994; Papavizas, 1968; Reddy and Patrick, 1989). Thielaviopsis basicola has the ability to parasitize a wide range of important agricultural hosts, including cotton (Gossypium hirsutum L.), bean (Phaseolus vulgaris L.), carrot (Daucus carota L.), pansy (Viola tricolor var. hortensis DC.), peanut (Arachis hypogaea L.), and tobacco (Nicotiana tabacum L.) (Hood and Shew, 1996, 1997a; Smith, 1960; Snyder et al., 1959). After infection, the fungus causes both black root rot diseases and seedling damping-off. In Canada, this pathogen causes black root rot on carrot (Daucus carota) (Punja et al., 1992) and tobacco (Nicotiana tabacum) (Schipper, 1970; Gayed, 1972; Stover, 1950; Stover, 1956) while also inducing disease on ornamental species such as poinsettia [Euphorbia pulcherrima (Willd. ex Klotzsch) Graham] and petunia (Petunia hybrida Vilm.) (Mims et al., 2000; Punja et al., 1999). Identification of this pathogen is straightforward because the fungus produces two distinctive spore types, chlamydospores (aleuriospores) and phialospores (endoconidia). Chlamydospores are characterized by their thick pigmented walls divided into distinct compartments or segments with each able to germinate (Wheeler and Stipanovic, 1979; Wick and Moore, 1983). Phialospores, on the other hand, are hyaline, nondivided, and have a rectangular shape (Arseniuk and Czembor, 1999; Shew and Meyer, 1992; Hood and Shew, 1997b; Jones, 1991; Tabachnik et al., 1979).

Little is known about the factors (e.g., cultural conditions, host plant genetics) that affect DSDS development beyond anecdotal observations and practices. For example, during nursery production of daphne cultivars, many producers apply prophylactic fungicide treatments to help ensure crop health. Although this is a relatively common practice, no published literature was found that directly addresses the efficacy of this practice to control DSDS. In addition, even if effective at controlling DSDS, reliance on fungicides is unsustainable and undesirable. One alternative to this practice is the development of disease-resistant daphne cultivars. This strategy is typically more desirable because it can be highly effective in reducing disease, is environmentally benign, and usually entails little or no additional expense to producers (Crute and Pink, 1996; Dahlberga and Bandyopadhyay, 2001; Diaz-Pérez, 1995; Reeleder, 1999). However, it typically requires a long time horizon to achieve. To date, native host plant resistance to $T$. basicola has been identified during germplasm screens as part of various crop improvement or breeding programs. For example, Nicotiana glauca Graham was identified as resistant to $T$. basicola and subsequently incorporated into a tobacco ( $N$. tabacum) breeding program (Trojak-Goluch, 2005). In another germplasm screen, Gossypium arboreum L. PI 1415 was found to be resistant to $T$. basicola and subsequently incorporated into a diploid cotton-breeding program (Berbec and Berbec, 1976; Shankara and Cowling, 1999; Wheeler et al., 1999). Based on these reports, evaluating Daphne germplasm for resistance to DSDS, through controlled screens, is a reasonable approach to identify host plant resistance to this pathogen. Therefore, the objectives of this study were 1) to develop an efficient method for evaluating resistance of Daphne spp. to T. basicola; 2) to compare in vivo and in vitro methods for their efficiency in identifying resistance of selected Daphne taxa; 3) to develop a useful disease progression index (DPI) for use in taxa evaluations; and 4) to rank Daphne germplasm for resistance to T. basicola.

\section{Materials and Methods}

Plant material. Thirty-two species and cultivars of Daphne were collected and maintained at the UBC Botanical Garden and Center for Plant Research, Vancouver, BC, Canada. All 32 taxa were included in an in vivo challenge while a subset of seven 
species were used in an in vitro challenge (Table 1). Container-grown stock plants were used to supply tissue for both in vitro tissue culture establishment and traditional vegetative propagation. Rooted plants were produced in July and August from terminal cuttings (50 to $100 \mathrm{~mm}$ in length) with the flower buds and lower leaves removed. Cuttings were made with a single shallow cut and soaked in an antifungal solution (Physan 20; Maril Products) for $60 \mathrm{~s}$. The cuttings were allowed to dry momentarily before being dipped in $0.4 \%$ IBA powder (Stim Root \#2; Plant Products Co. Ltd., Brampton, Ontario, Canada) and then placed in 6-cm pots filled with a course rooting medium [10 parts propagation grade perlite, 8 parts peat, 6 parts granite grit $\# 2,1$ part pumice (double screened to remove fine particles), dolomite lime 65AG at $900 \mathrm{~g} \cdot \mathrm{m}^{-3}$, and Micromax (Scotts, Georgetown, Ontario, Canada) (trace elements) at $\left.400 \mathrm{~g} \cdot \mathrm{m}^{-3}\right]$. The flats were placed under intermittent mist with bottom heat set at $22{ }^{\circ} \mathrm{C}$. Rooted cuttings were transferred to a polyhouse in October where they were allowed to go dormant but kept frost-free. They were repotted in May into $12-\mathrm{cm}$ pots filled with a well-drained medium $[8$ parts peat, 8 parts Turface MVP, 6 parts granite grit \#2, 4 parts screened and pasteurized soil, 1 part pumice, dolomite lime $65 \mathrm{AG}$ at 670 $\mathrm{g} \cdot \mathrm{m}^{-3}$, Micromax micronutrients at 540 $\mathrm{g} \cdot \mathrm{m}^{-3}$, Osmocote 18-6-12 (Scotts, Georgetown, Ontario, Canada) at $2150 \mathrm{~g} \cdot \mathrm{m}^{-3}$, and Psi Matric (TerraLink Horticulture, Abbotsford, BC, Canada) wetting agent]. All stock plants were grown under shadecloth during the summer months and moved to a heated polyhouse during the winter months to prevent frost damage. Fertilization regiment included yearly top-dressing with Osmocote 18-6-12 at $5 \mathrm{~g} / 1$-gal pot. Fungicides were not used during stock production because we had very little disease pressure and we did not want to risk crosscontamination affecting the in vivo assay.

Pathogen culture and suspension preparation. A single aggressive pathogenic isolate of $T$. basicola was cultured from diseased daphne plants and used throughout this study (Noshad et al., 2006). A suspension of endoconidia was prepared by gently washing the surface of 3-week-old colonies with deionized water and vortexing the wash solution for $30 \mathrm{~s}$. The resulting suspension was filtered twice through four layers of cheesecloth to remove agar, hyphae, and chlamydospores. The spore suspension was calibrated with a hemocytometer and adjusted with deionized water to obtain a final concentration of endoconidia of $1 \times 10^{6} \mathrm{~mL}^{-1}$ before inoculation.

In vivo challenge. The conidial suspension $(5 \mathrm{~mL})$ was topically applied to healthy roots of 2-year-old nursery-grown plants. Production containers were modified to contain a clear panel behind a lightproof "door" to allow for direct observation of the infection process without further disturbance to the root system (Fig. 1A). All procedures were the same for control plants except for the application of distilled water instead of the spore suspension. To allow for uniform conditions after inoculation, plants were transferred to a greenhouse and grown under natural light at $25 \pm 1{ }^{\circ} \mathrm{C}$ and a relative humidity between $70 \%$ and $80 \%$.

In vitro challenge. Seven of the 32 taxa were selected for inclusion in an in vitro challenge (Fig. 2). Clean cultures of these taxa were established and axillary shoot proliferation obtained from nodal explants cultured on either MS (Murashige and Skoog, 1962) or Woody Plant Medium (McCown and Lloyd, 1983) supplemented with various concentrations of plant growth regulators [i.e., indole 3-butyric acid (IBA),

Table 1. Daphne taxa used in the Thielaviopsis basicola resistance bioassay with region of nativity or origin and mean plant disease index (PDI) values 8 weeks after inoculation.

\begin{tabular}{|c|c|c|}
\hline Taxa & Nativity/origin & Mean PDI $(\mathrm{sD})^{\mathrm{z}}$ \\
\hline D. alpina L. & Italy & $12.5(0.92)^{\text {ghi }}$ \\
\hline D. arbuscula Celak. & Czech Republic & $43.3(1.74)^{\text {abcdef }}$ \\
\hline D. bholua Buch-Ham. ex & Nepal & $12.5(0.82)^{\text {ghi }}$ \\
\hline D. Xburkwoodii 'Carol Mackie' & Horticultural origin & $29.2(1.32)^{\text {cdefgh }}$ \\
\hline D. caucasica Pall. & Russia & $9.2(1.02) \mathrm{hi}$ \\
\hline D. circassica $\mathrm{L}$. & Russia & $46.6(1.66)^{\text {abcde }}$ \\
\hline D. cneorum L. & Czeck Republic & $64.2(1.89)^{\mathrm{a}}$ \\
\hline D. collina Smith & Turkey & $51.7(1.31)^{\mathrm{abcd}}$ \\
\hline D. Xeschmannii & Horticultural origin & $23.3(1.17)$ defghi \\
\hline D. genkwa Siebold \& Zucc. & China & $43.3(1.31)^{\text {abcdef }}$ \\
\hline D. genkwa (Hackenberry group) & Horticultural origin & $15.0(1.22)^{\text {fghi }}$ \\
\hline D. ginidium $\mathrm{L}$ & Spain & $27.5(1.22)$ defgh \\
\hline D. giraldii Nitsche & W. China & $15.8(1.18)^{\text {fghi }}$ \\
\hline D. jasminea Sibth. \& Sm. & Greece & $13.3(1.09)^{\text {fghi }}$ \\
\hline D. kosaninii Stoj. & Bulgaria & $20.8(1.3)^{\text {efghi }}$ \\
\hline D. laureola $\mathrm{L}$. & N. Africa & $23.3(1.34)$ defghi \\
\hline D. 'Lawrence Crocker' & Horticultural origin & $40.8(1.80)^{\text {abcdefg }}$ \\
\hline D. longilobata Turril. & China-Yunnan & $30.8(1.06)^{\text {cdefgh }}$ \\
\hline D. Xmantensiana & Horticultural origin & $57.5(1.87)^{a b c}$ \\
\hline D. mezereum L. & Russia & $10.0(1.02)^{h i}$ \\
\hline D. mezereum (alba) & Horticultural origin & $15.0(1.32)^{\text {ghi }}$ \\
\hline D. Xnapolitana & Horticultural origin & $39.2(1.46)^{\text {abcdefg }}$ \\
\hline D. odora Auct. & China & $31.7(1.21)^{\text {cdefgh }}$ \\
\hline D. oleoides Schreber & Turkey & $17.5(1.19)$ fghi \\
\hline D. pontica L. & Russia & $60.8(1.54)^{a b}$ \\
\hline D. retusa Hemsl. & China & $0.0(0)^{\mathrm{j}}$ \\
\hline D. Xrollsdorfii 'Arnold Cihlarz' & Horticultural origin & $25.8(1.54)$ defghi \\
\hline D. rossettii Gab. & Horticultural origin & $15.8(1.06)$ fghi \\
\hline D. Xthauma & Horticultural origin & $34.2(1.40)$ bcdefgh \\
\hline D. tangutica Maxim. & China & $0.0(0)^{\mathrm{j}}$ \\
\hline D. transcaucasica Pobed. & Turkey & $19.2(1.30))^{\text {efghi }}$ \\
\hline D. 'Whilhelm Shacht' & Horticultural origin & $19.2(1.18)^{\text {defghi }}$ \\
\hline
\end{tabular}

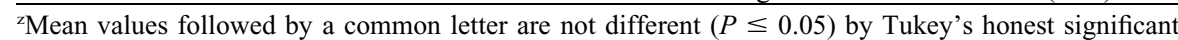
differences test.
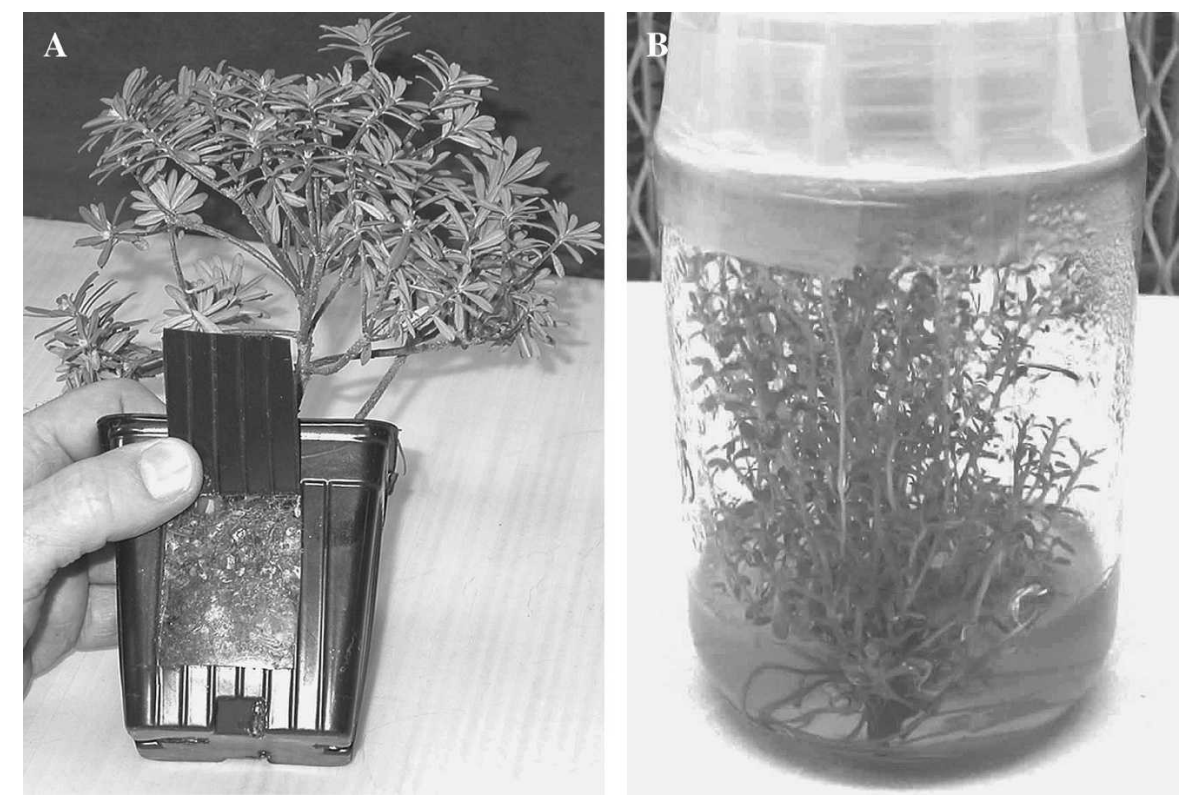

Fig. 1. Bioassay containers used for Daphne taxa challenged with Thielaviopsis basicola; (A) in vivo assay pots modified with viewing panel for direct observation of diseased roots; (B) in vitro assay with conidial suspension injected next to a root segment while still embedded in the culture medium. 


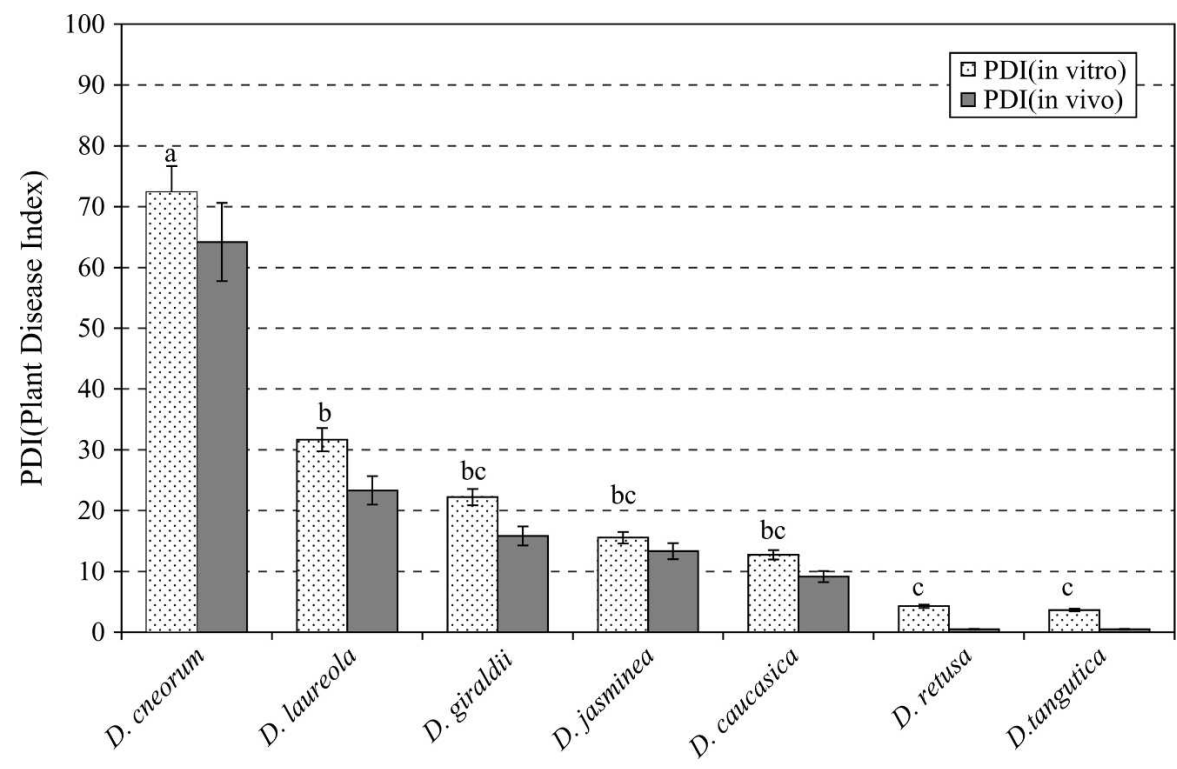

Taxa

Fig. 2. Comparison of the in vitro with in vivo assays using seven Daphne taxa and Thielaviopsis basicola. Plant disease index (PDI) values are presented at 5 weeks after inoculation; bars marked with the same letter do not differ significantly; error bars $=\mathrm{SD}$.

$\alpha$-naphthalene acetic acid (NAA) and 6-benzyl aminopurine (BA)], minerals, and agar. All the in vitro plant cultures were maintained at $24{ }^{\circ} \mathrm{C}$ with a $16 / 8$-h photoperiod supplied by cool-white fluorescent lamps delivering 350 $\mu \mathrm{W} \cdot \mathrm{cm}^{-2}$. Axillary shoots were rooted by subculturing on MS medium supplemented with NAA and IBA. After 6 to 8 weeks, shoots were rooted and ready for inoculation. Using a 1-mL syringe, $1 \mathrm{~mL}$ of the conidial suspension was injected next to a root segment while still embedded in the culture medium (Fig. 1B). All control plants were treated equally to the test plants except for injection of distilled water instead of the conidial suspension (Jarausch and Lansac, 1999; Svabova, 2005).

Disease assessment. For both methods, observations on disease progression after inoculation were made weekly over 8 weeks. The following disease progression rating (DPR) was developed: $0=$ healthy plant, no symptoms; $1=$ less than five lesions on lateral roots, no lesions on tap root, no foliar symptoms; 2 = greater than five lesions on lateral roots, less than five lesions on tap root, no foliar symptoms; 3 = most lateral roots with lesions and some necrosis, greater than five lesions on tap root, five to 10 chlorotic leaves; $4=$ most lateral roots necrotic, greater than five lesions on tap root, most leaves chlorotic with some leaf abscission; or $5=$ plant is dead. A plant disease index (PDI) was developed based on both disease incidence (DI) and disease severity (DS) as follows:

$$
\mathrm{PDI}=\mathrm{DS} / \mathrm{L} \times \mathrm{DI} / \mathrm{N} \times 100
$$

where DS = disease severity (i.e., average DPR value among diseased plants); $\mathrm{L}=$ the number of DPR disease categories; DI = disease incidence (i.e., number of diseased plants); and $\mathrm{N}=$ total number of plants. This the most susceptible to $T$. basicola infection $($ PDI $=72.2)$, whereas $D$. tangutica and $D$. retusa were the most resistant $(\mathrm{PDI}=3.3$ and 3.58) (Fig. 2). For the five remaining taxa, PDI ranged between these extremes and with varying levels of chlorosis, leaf abscission, and stunting observed (Fig. 2).

Assay comparison. For the seven taxa included in both assays, strong similarities were present for overall taxa performance, whereas a significant difference in the timing of disease progression was present. A high correlation coefficient $(\mathrm{R}=0.87$ ) was calculated between these systems for PDI values, indicating both systems were comparable in evaluating disease susceptibility among these seven taxa. In addition, the rank order of taxa based on DPI values for the two methods were identical, further supporting these methods as equal in evaluating disease susceptibility. However, the in vitro system produced results in significantly less time. On average, 3 fewer weeks were required to reach the same level of disease progression as compared with the in vivo system.

\section{Discussion}

approach allows for greater resolution of absolute taxon susceptibility by combining both relative disease progression within individuals and the absolute occurrence of the disease within a taxon. Therefore, based on this assessment, a completely susceptible taxon would score 100, whereas a completely resistant taxon would score 0 .

Data analyses. Both methods used a completely randomized design with three replications. Each replication consisted of 24 plants per taxon with two plants serving as controls. Descriptive statistics, analysis of variance, correlation, and Tukey's honest significant differences test were generated using SPSS 11.5 software (SPSS, Statistical Package for the Social Sciences, Chicago).

\section{Results}

In vivo screen. Significant differences $(P<$ 0.05 ) among taxa were observed for PDI values of T. basicola infection. Eight weeks after inoculation, PDI values ranged from 64.6 for D. cneorum to 0 for D. tangutica and $D$. retusa (Table 1). For all other taxa, PDI values ranged between these extremes and with varying levels of chlorosis, leaf abscission, and stunting observed. Typical disease progression in susceptible taxa can be generalized as follows: 1 to 3 weeks postinoculation, brown to black necrotic lesions on the roots; 4 to 6 weeks postinoculation, leaf chlorosis leading to abscission; and 6 to 8 weeks postinoculation, whole plant stunting, stem collapse, and plant death. However, for highly resistant taxa, no visible infection or discoloration developed at any time.

In vitro screen. Similar to the in vivo challenge, significant differences between the susceptible and resistant taxa evaluated were identified for $T$. basicola development. Like in the in vivo screen, D. cneorum was
The identification and incorporation of host-plant resistance into susceptible plants is an often sought-after goal for many breeding programs. It has been successfully achieved using both conventional breeding as well as biotechnological methods. However, despite significant differences between these two approaches, both rely on a robust germplasm screen to differentiate germplasm performance after pathogen exposure. A screen incorporated into a traditional breeding program often involves the evaluation of progeny derived from hybridizations between resistant and susceptible parents or the evaluation of related taxa if resistance was not present in the most advanced gene pool (Agrios 1997; Daryonol and Natsuaki, 2005; Iglesias and Pico, 2000; Punja, 2001). This approach has been successfully used to transfer $T$. basicola resistance between related species. In independent breeding programs, T. basicola-resistant tobacco genotypes were developed based on germplasm screens of related Nicotiana species (Bai et al., 1996; Palakarcheva, 1995; Trojak, 2005). Specifically, the use of a robust germplasm screen allowed researchers to identify $T$. basicola resistance in Nicotiana debneyi (Bai et al., 1996; Wilkinson and Rufty, 1991) and to further conclude it was conditioned by a single dominant gene. Once transferred to a susceptible genetic background, this gene conferred the same degree of resistance as found in the original $N$. debneyi accession (Bai et al., 1996; Keller et al., 1999; Legg and Litton, 1981; Palakarcheva, 1995,). In a Gossypium germplasm screen designed to identify $T$. basicola resistance, significant variation was observed among taxa with the strongest resistance identified in Gossypium arboreum. This resistance was then successfully transferred to commercial cotton cultivars (Rothrock, 1992; Walker et al., 1999; 
Wheeler et al., 1999). Development of a robust $T$. basicola germplasm screen is valuable in not only identifying taxon-specific variation for pathogen resistance, but also for further evaluation of the plant's genetic structure. Among the 32 Daphne taxa evaluated, significant differences were present for resistance to $T$. basicola under both in vivo and in vitro challenges. Of the 32 taxa, $D$. tangutica and $D$. retusa displayed the greatest resistance and remained symptom-free during the in vivo challenges while displaying only mild symptoms in the in vitro challenges. At the other extreme, Daphne cneroum was clearly the most susceptible taxon in both screens and became fully diseased followed by plant death in the shortest amount of time. The observed range in disease resistance among Daphne taxa indicates our challenge was effective and identifies $D$. tangutica and D. retusa as potential sources for resistance.

The inoculation and screening methods were proven robust in terms of the isolate's pathogenicity, disease characterization, consistency over time, and in its ability to differentiate taxa. Based on the one isolate used, overall pathenogenicity was adequate in allowing assessment of disease incidence and severity (i.e., root and foliar symptoms) on all taxa. Also, the concentration of conidia used was sufficient to cause disease but not to overwhelm the defense mechanism(s) and prevent taxa differences from being displayed. Finally, both screening methods produced comparable and consistent results over an 11-month period despite the in vivo challenge being conducted in an outdoor polyhouse exposed to seasonal fluctuations. These observations validate our screen methodology and support its continued use in identifying genetic variation among Daphne species for resistance to DSDS.

The results of the in vitro and in vivo experiments indicate a strong correlation between these two assay methods. However, there were differences in disease progression rates between them. Typically, the in vitro challenge produced a comparable level of disease as the in vivo challenge but in 2 to 3 weeks' less time. Differences in disease development rates between plants produced from tissue culture and traditional propagation have been reported and may be based on anatomical (e.g., root structure), biological (e.g., adaptation mechanisms with other organisms), or physiological (e.g., difference in biochemical compounds) differences (DiazPérez, 1995). Further research into these differences may reveal important information on the pathogen infection process and the various factors that influence both successful infection and successful defense.

\section{Literature Cited}

Adams, P.B. and G.C. Papavizas. 1969. Survival of root-infecting fungi in soil. Phytopathology. 59:135-138.

Agrios, G.N. 1997. Plant pathology. 4th ed. Academic Press, San Diego.
Anderson, T.R. and T.W. Welacky. 1988. Populations of Thielaviopsis basicola in burley tobacco field soils and the relationship between soil inoculum concentration and severity of disease on tobacco and soybean seedlings. Can. J. Plant Pathol. 10:246-251.

Arseniuk, E. and P.C. Czembor. 1999. Host-parasite interactions: Septoria and Stagonospora diseases of cereals: A compilation of global research. Mexico, DF: CIMMYT. p. 63-70.

Bai, D.P., R. Reeleder, and J.E. Brandle. 1996. Production and characterization of tobacco addition lines carrying $N$. debneyi chromosomes with a gene for resistance to black root rot. Crop Sci. 36:852-857.

Berbec, J. and A. Berbec. 1976. Growth and development of Nicotiana tabacum L. from reconstituted on the cytoplasm of Nicotiana glauca Grah. Genet. Polonica 17:309-318.

Bottacin, A.M., C.A. Lévesque, and Z.K. Punja. 1994. Characterization of dsRNA in Chalara elegans and effects on growth and virulence. Phytopathology. 84:303-312.

Crute, I.R. and D.A.C. Pink. 1996. Genetics and utilization of pathogen resistance in plants. Plant Cell 8:1747-1755.

Dahlberga, J.A. and R. Bandyopadhyay. 2001. Evaluation of sorghum germplasm used in US breeding programmes for sources of sugary disease resistance. Plant Pathol. 50:681-689.

Daryonol, B.S. and K.T. Natsuaki. 2005. Screening for resistance to Kyuri green mottle mosaic virus in various melons. Plant Breed. 124:487490.

Diaz-Pérez, J. 1995. Acclimatization and subsequent gas exchange, water relations, survival and growth of microcultured apple plantlets after transplanting them in soil. Physiol. Plant. 95:225-229.

Flora of China. Vol. 13 (Clusiaceae through Araliaceae). Science Press, Beijing, and Missouri Botanical Garden Press, St. Louis (in press).

Gayed, S.K. 1972. Host range and persistence of Thielaviopsis basicola in tobacco soil. Can. J. Plant Sci. 52:869-873.

Hood, M.E. and H.D. Shew. 1996. Pathogenesis of Thielaviopsis basicola on a susceptible and resistant cultivar of burley tobacco. Phytopathology. 86:38-44.

Hood, M.E. and H.D. Shew. 1997a. Initial cellular interactions between Thielaviopsis basicola and tobacco root hairs. Phytopathology. $87: 228-235$.

Hood, M.E. and H.D. Shew. 1997b. Reassessment of the role of saprophyti activity in the ecology of Thielaviopsis basicola. Phytopathology. 87:1214-1219.

Iglesias, A. and B. Pico. 2000. Pathogenicity of fungi associated with melon vine decline and selection strategies for breeding resistant cultivars. Ann. Appl. Biol. 137:141-151.

Jarausch, W. and M. Lansac. 1999. Phytoplasma transmission by in vitro graft inoculation as a basis for a preliminary screening method for resistance in fruit trees. Plant Pathol. 48:283-287.

Jones, B.L. 1991. Penetration and development of Chalara elegans in peanut (Arachis hypogaea). Phytophylactica 23:81-84.

Keller, H., N. Pamboukdjian, A. Ponchet, and A. Poupet. 1999. Induced elicitin production in transgenic tobacco generates a hypersensitive response and nonspecific disease resistance. Plant Cell 11:223-235.

King, C.J. and J.T. Presley. 1942. A root rot of cotton caused by Thielaviopsis basicola. Phytopathology. 32:752-761.

Legg, P.D. and C.C. Litton. 1981. Effect of Nicotiana debneyi black root rot resistance factor on agronomic and chemical traits in burley tobacco. Theor. Appl. Genet. 60:365-368.

McCown, B. and G. Lloyd. 1983. A survey of the response of Rhododendron to in vitro culture. Plant Cell, Tissue Org. Cult. 2:77-85.

Mims, C.W., W.E. Copes, and E.A. Richardson. 2000. Ultrastructure of the penetration and infection of pansy roots by Thielaviopsis basicola. Phytopathology. 90:843-850.

Murashige, T. and F. Skoog. 1962. A revised medium for rapid growth and bioassays with tobacco tissue cultures. Physiol Plant. 15:473497.

Nag Raj, T.R. and B. Kendrick. 1975. A monograph of Chalara and allied genera. Wilfred Laurier University Press, Waterloo, Ontario.

Noshad, D., Z.K. Punja, and A. Riseman. 2006. First report of Thielaviopsis basicola on Daphne cneorum. Can. J. Plant Pathol. 28:310-312.

Palakarcheva, M. 1995. Transfer of disease resistance genes by interspecific hybridization of wild growing Nicotiana species in Nicotiana tabacum. J. Genet. Breed. 94:99-105.

Papavizas, G.C. 1968. Survival of root-infecting fungi in soil. Phytopathology. 58:421-428.

Punja, Z.K. 2001. Genetic engineering of plants to enhance resistance to fungal pathogens, a review of progress and future prospects. Can. J. Plant Pathol. 23:216-235.

Punja, Z.K., S. Chittaranjan, and M.M. Gaye. 1992. Development of black root rot caused by Chalara elegans on fresh market carrots. Can. J. Plant Pathol. 14:299-309.

Punja, Z.K. and L.J. Sun. 1999. Morphological and molecular characterization of Chalara elegans (Thielaviopsis basicola), cause of black root rot on diverse plant species. Can. J. Bot. 77:18011812 .

Reddy, M.S. and Z.A. Patrick. 1989. Effects of host, nonhost, and fallow soil on populations of Thielaviopsis basicola and severity of black root rot. Can. J. Plant Pathol. 11:68-74.

Reeleder, R. 1999. Septoria leaf spot of Stevia rebaudiana in Canada and methods for screening for resistance. J. Phytopathol. 147:605613.

Rothrock, C.S. 1992. Influence of soil temperature, water, and texture on Thielaviopsis basicola and black root rot on cotton. Phytopathology. 82:1202-1206.

Schipper, B. 1970. Survival of endoconidia of Thielaviopsis basicola in soil. Netherlands J. Plant Pathol. 76:206-211.

Shankara, M. and W.A. Cowling. 1999. Screening for resistance to Diaporthe toxica in lupins by estimation of phomopsins and glucoseamine in individual plants. Plant Pathol. 48:320-324.

Shew, H.D. and J.R. Meyer. 1992. Thielaviopsis, p. 171-174. In: L.L. Singleton, J.D. Mihail, and C.M. Rush (eds.). Methods for research on soilborne phytopathogenic fungi. Amer. Phytopathol. Soc., St. Paul, MN.

Smith, J.G. 1960. The influence of antagonistic fungi on Thielaviopsis basicola (Berk. et Br.). Ferraris. Acta Bot. Neerlandica 9:59-118.

Snyder, W.C., M.N. Schroth, and T. Christou. 1959. Effect of plant residues on root rot of bean. Phytopathology. 49:755-756.

Stover, R.H. 1950. The black root rot disease of tobacco. I. Studies on the causal organism Thielaviopsis basicola. Can. J. Bot. 28:445-470.

Stover, R.H. 1956. Effect of nutrition on growth and chlamydospore formation in brown and gray cultures of Thielaviopsis basicola. Can. J. Bot. 34:459-472.

Svabova, L. 2005. In vitro selection for improved plant resistance to toxin-producing pathogens. Phytopathology. 153:52-64. 
Tabachnik, M., J.E. DeVay, R.H. Garber, and R.J. Wakeman. 1979. Influence of soil inoculum concentrations on host range and disease reactions caused by isolates of Thielaviopsis basicola and comparison of soil assay methods. Phytopathology. 69:974-977.

Trojak-Goluch, A. and A. Berbeć. 2005. Potential of Nicotiana glauca (Grah.) as a source of resistance to black root rot Thielaviopsis basicola (Berk. and Broome) Ferr. in tobacco improvement. Plant Breed. 124:507-510.
Walker, N.R., T.L. Kirkpatrick, and C.S. Rothrock. 1999. Effect of temperature on and histopathology of the interaction between Meloidogyne incognita and Thielaviopsis basicola on cotton. Phytopathology. 89:613617.

Wheeler, M.H. and R.D. Stipanovic. 1979. Melanin biosynthesis in Thielaviopsis basicola. Exp. Mycol. 3:340-350.

Wheeler, T.A., J.R. Gannaway, and K. Keating. 1999. Identification of resistance to Thielaviop- sis basicola in diploid cotton. Plant Dis. 83:831-833.

Wick, R.L. and L.D. Moore. 1983. Histopathology of root disease incited by Thielaviopsis basicola in Ilex crenata. Phytopathology. 73:561564.

Wilkinson, C.A. and R.C. Rufty. 1991. Inheritance of partial resistance to black root rot in burley tobacco. Plant Dis. 75:889-892.

Yarwood, C.E. 1981. Occurrence of Chalara elegans. Mycology. 73:524-530. 